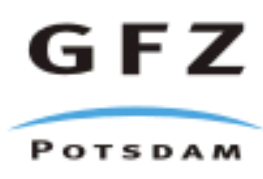

Originally published as:

Arvidsson, R., Gregersen, S., Kulhánek, O., Wahlström, R. (1991): Recent Kattegat earthquakes - evidence of active intraplate tectonics in southern Scandinavia. - Physics of the Earth and Planetary Interiors, 67, 3-4, 275-287. 


\title{
Recent Kattegat earthquakes - evidence of active intraplate tectonics in southern Scandinavia
}

\author{
Ronald Arvidsson ${ }^{\text {a }}$, Søren Gregersen ${ }^{\text {b }}$, Ota Kulhánek and Rutger Wahlström ${ }^{\text {a }}$ \\ ${ }^{a}$ Seismological Department, Uppsala University, Box 12019, S-750 12 Uppsala, Sweden \\ ${ }^{b}$ National Survey and Cadastre, Rentemestervej 8, DK-2400 Copenhagen NV, Denmark \\ (Received 15 November 1990; revision accepted 24 January 1991)
}

\begin{abstract}
Arvidsson, R., Gregersen, S., Kulhánek, O. and Wahlström, R., 1991. Recent Kattegat earthquakes - evidence of active intraplate tectonics in southern Scandinavia. Phys. Earth Planet. Inter., 67: 275-287.

On June 15,1985 , an earthquake with a local magnitude $M_{\mathrm{L}}$ (UPP) value of 4.6 occurred in the Kattegat area close to the Swedish-Danish border. It was one of the largest earthquakes in Sweden and Denmark during this century. Two more events occurred in the same area: on April 1, $1986\left(M_{\mathrm{L}}(\mathrm{UPP})=4.2\right)$, and May 24, $1990\left(M_{\mathrm{L}}(\mathrm{UPP})=3.3\right)$. The derived focal mechanisms have north-south trending $P$-axes which deviate by $45^{\circ}$ from the NW-trending compressive stress field postulated by the ridge-push theory. The mechanisms can, however, be explained by local neotectonism. Both the locations and focal mechanisms, strike-slip faulting on NW striking planes, correlate well with the dominant neotectonic feature of the region, the Skälderviken depression. Seismic moments of the 1985,1986 and 1990 events were $3.6 \times 10^{14} \mathrm{Nm}, 1.4 \times 10^{14} \mathrm{Nm}$ and $6.0 \times 10^{12} \mathrm{Nm}$, respectively. The 1985 earthquake had an estimated maximum intensity of VII (modified Mercalli scale) and was felt over an area with a mean radius of $180 \mathrm{~km}$. The 1986 earthquake had a maximum estimated intensity of VI and a radius of perceptibility of $100 \mathrm{~km}$. Despite the recent low seismicity of the area, the earthquakes studied here indicate the potential for the occurrence of major events. This is supported by the historical seismicity.
\end{abstract}

\section{Introduction}

The Tornquist zone which extends through southern Sweden and the Kattegat marine area constitutes the southern boundary of the Baltic Shield. This zone and the nearby and similarly oriented Anholt fault and Skälderviken depression (Fig. 1) are known as areas of low seismic activity.

In spite of the generally low seismicity of southern Sweden and neighbouring parts of Denmark (Fig. 2), a few larger earthquakes have occurred within this region. An earthquake on December 21, 1759, magnitude around 5.5, is one of the largest earthquakes of the past half millenium (Wahlström, 1990) to occur in the region, but its location was likely north of the area where the earthquakes we study here occurred (see e.g. Husebye et al., 1978, Ambraseys, 1985, Muir
Wood, 1988). An event on October 31, 1930 (Båth, 1956) was located about $150 \mathrm{~km}$ to the south of the earthquakes studied here (Fig. 1). Even though information based on data from historical earthquakes is less reliable than that from the period of modern seismographs, the 1759 and 1930 events indicate the potential of the area to generate larger earthquakes.

On June 15, 1985, the largest earthquake in Sweden and Denmark in many decades occurred in Kattegat. The epicentre was located slightly north of the Tornquist zone, close to the Swedish-Danish border. Larger earthquakes took place nearby on April 1, 1986, and May 24, 1990 (Fig. 1). The three events were well recorded by a number of seismograph stations and provide a large amount of new information on the seismotectonics of the region, which was previously based 


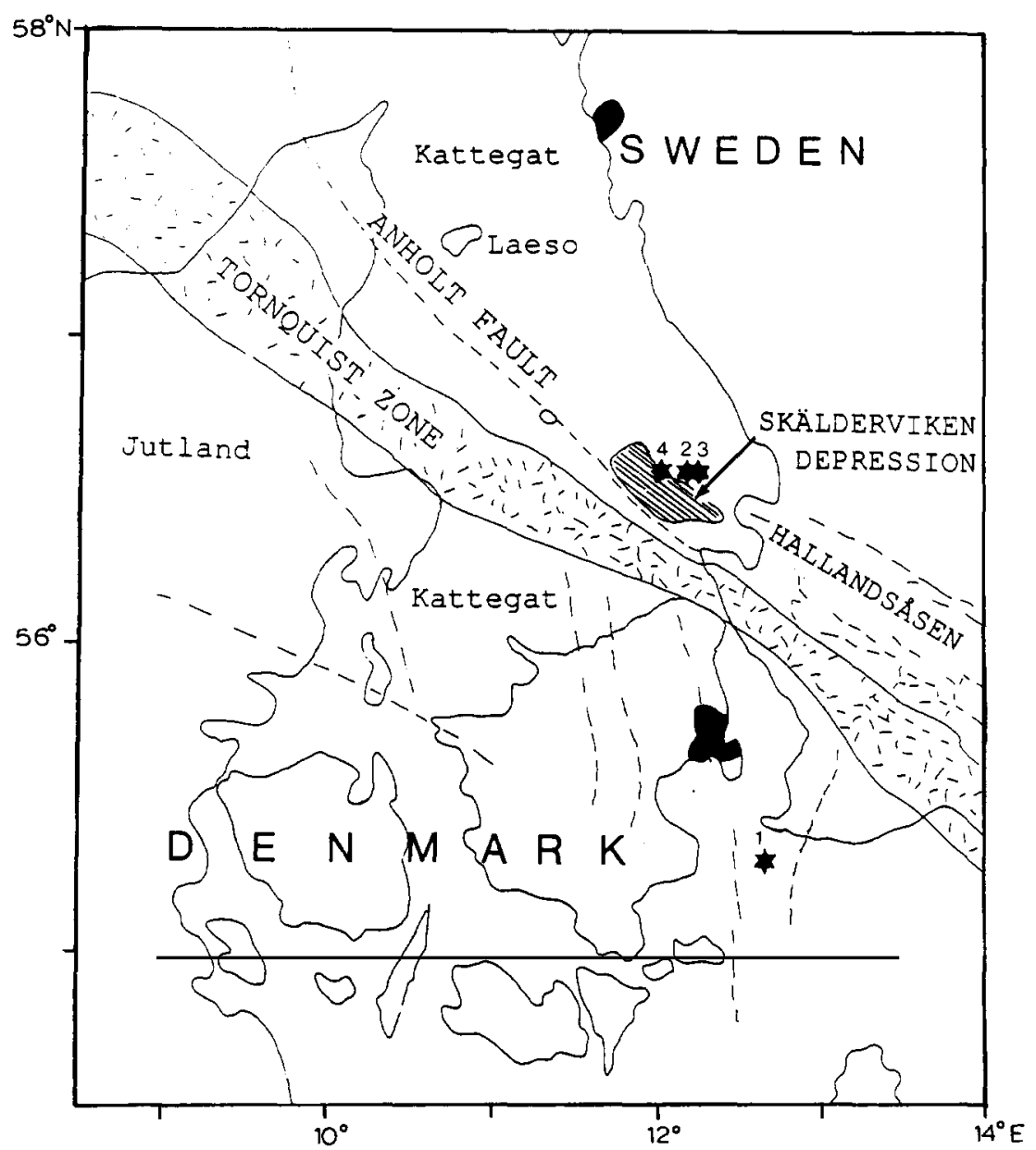

Fig. 1. Major tectonic features in Kattegat. The stars denote epicentres of the 1930 (1), 1985 (2), 1986 (3) and 1990 (4) earthquakes. The cities of Copenhagen (Denmark) and Göteborg (Sweden) are marked in black. Modified map after EUGENO-S working group (1988).

largely on less reliable data from historical events. The main objective of this work is to analyse the three quakes by making use of macroseismic and instrumental data for location, focal mechanism, dynamic source parameters and correlation with regional geology.

\section{Tectonics and seismicity}

The three earthquakes investigated in this study occurred in Kattegat, close to the Tornquist zone and the Anholt fault, two major regional tectonic features in southern Sweden and Denmark, strik- ing in the NW direction (Fig. 1). The Tornquist zone, which constitutes the southern border zone of the Baltic Shield, is a linear belt of complex structure with a width varying from $20 \mathrm{~km}$ to 150 $\mathrm{km}$ (Pegrum, 1984). The zone has been subjected to tectonic deformations through both compressional and extensional regimes at various periods beginning in the late Precambrian (Bergström, 1984) and continuing into the Tertiary (Pegrum, 1984). The Anholt fault runs parallel to the Tornquist zone in southern Kattegat (Pegrum, 1984) but diverges from this zone towards the north. 


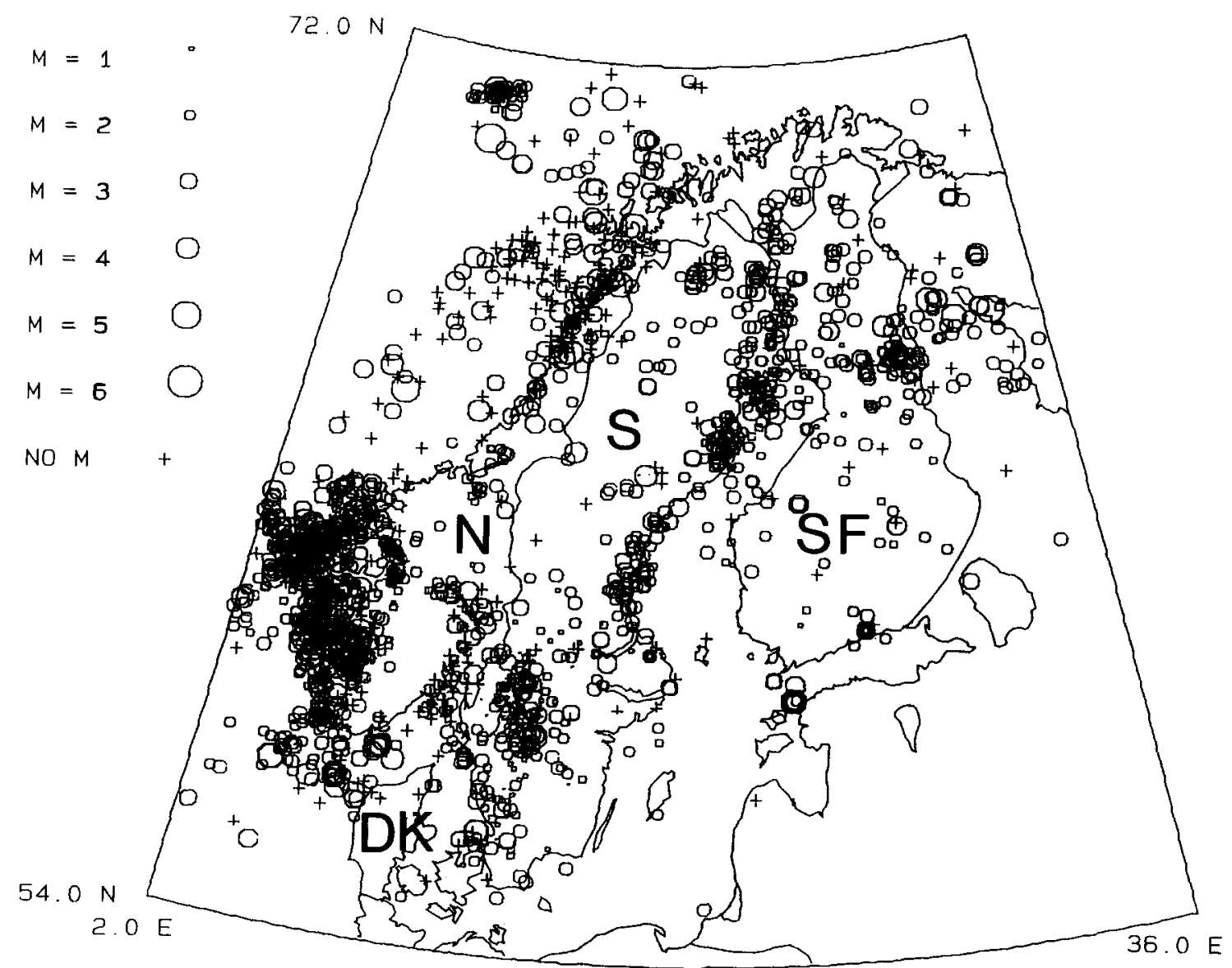

Fig. 2. Epicentres of earthquakes in Fennoscandia for the period 1950-1989. DK = Denmark, $N=$ Norway, $S=$ Sweden, $S F=$ Finland. Data plotted are those given in the FENCAT catalogue of the Seismological Institute, University of Helsinki. The present authors made no efforts to remove possible explosions, rockbursts, aftershocks etc. from the data base.

Close to the Swedish coast and in the immediate vicinity of the studied earthquakes, i.e. to the northeast of the actual Tornquist zone, is located one of Kattegat's most pronounced neotectonic features, the Skälderviken depression. Interpretations from seismic refraction profiles across the depression show a gradual increase of Quaternary deposits from SW to NE, probably related to the subsidence initiated in the Holstein, during the later part of the Pleistocene, due to tensional stresses acting in the SW direction (Lykke-Andersen, 1987). Interpretation of recent refraction and reflection seismic investigations indicate normal faulting in Quaternary deposits in the northwestern flank of the depression, probably related to reactivation of more deep-seated faults (Lind and Lykke-Andersen, 1990). Following the southeastern strike direction of this part of the depression towards the Swedish coast, we reach the Hallandsåsen horst where neotectonic movements have been observed and described by Mörner (1969). In summary, a persistance of deformation in the Kattegat area emphasizes the potential for seismic energy release.

Generally speaking, the seismicity in Sweden and Denmark shows a diffuse geographic distribution of epicentres and sporadic occurrence of larger shocks, which are typical features of intraplate seismicity. The recent seismic activity, as reported by FENCAT (1990), is shown in Fig. 2. For 
Denmark and Sweden the seismicity suggests the existence of zones of higher activity in the sea off the shoulder of northwestern Denmark, in southcentral Sweden, and along the northern coast and in the northernmost parts of Sweden. The seismicity near the area of the events studied is, by Scandinavian standards, rather moderate. The Tornquist zone itself has not as yet been considered as an area of larger seismic energy release. It seems that the zone delineates the southern edge of seismicity in Sweden. In Kattegat, the area around the Skälderviken depression is seismically the most active.

\section{Data and hypocentre location}

The 1985, 1986 and 1990 earthquakes were well recorded at epicentral distances of up to $15^{\circ}$. Data from analog and digital stations in Denmark, Finland, Germany, Holland, Norway and Sweden were used in the analysis. As an example, Fig. 3 shows analog plots of digital three-component, broad-band seismograms of the 1985 event made at Uppsala. The locations of stations used in the determination of $\mathbf{P}$-polarity readings, earthquake
TABLE 1

Velocity model (Båth, 1979) used in the location procedure

\begin{tabular}{lll}
\hline $\begin{array}{l}\text { Depth } \\
(\mathrm{km})\end{array}$ & Wave velocities \\
\cline { 2 - 3 } & $\begin{array}{l}\mathrm{P} \\
\left(\mathrm{km} \mathrm{s}^{-1}\right)\end{array}$ & $\begin{array}{l}\mathrm{S} \\
\left(\mathrm{km} \mathrm{s}^{-1}\right)\end{array}$ \\
\hline $0-19$ & 6.22 & 3.58 \\
$19-38$ & 6.64 & 3.69 \\
$38-$ & 7.84 & 4.55 \\
\hline
\end{tabular}

locations, fault-plane solutions and spectra are shown in Fig. 4. All three earthquakes have been located by using the HYPOINVERSE program (Klein, 1978) which makes use of the first $P$ and/or first $S$ onsets. Arrival-time readings were weighted according to the record quality. The program also makes use of an automatic weighting with respect to the epicentral distance and the travel-time residual. Altogether, 26 stations were used to locate the 1985 event, 21 stations for the 1986 event and 11 stations for the 1990 event. The respective distance ranges for the stations used in the locations were $70-960 \mathrm{~km}, 90-950 \mathrm{~km}$ and $90-470$ $\mathrm{km}$. A two-layered crustal model (Table 1) was applied for arrivals measured at Finnish, Norwegian and Swedish stations. For stations in
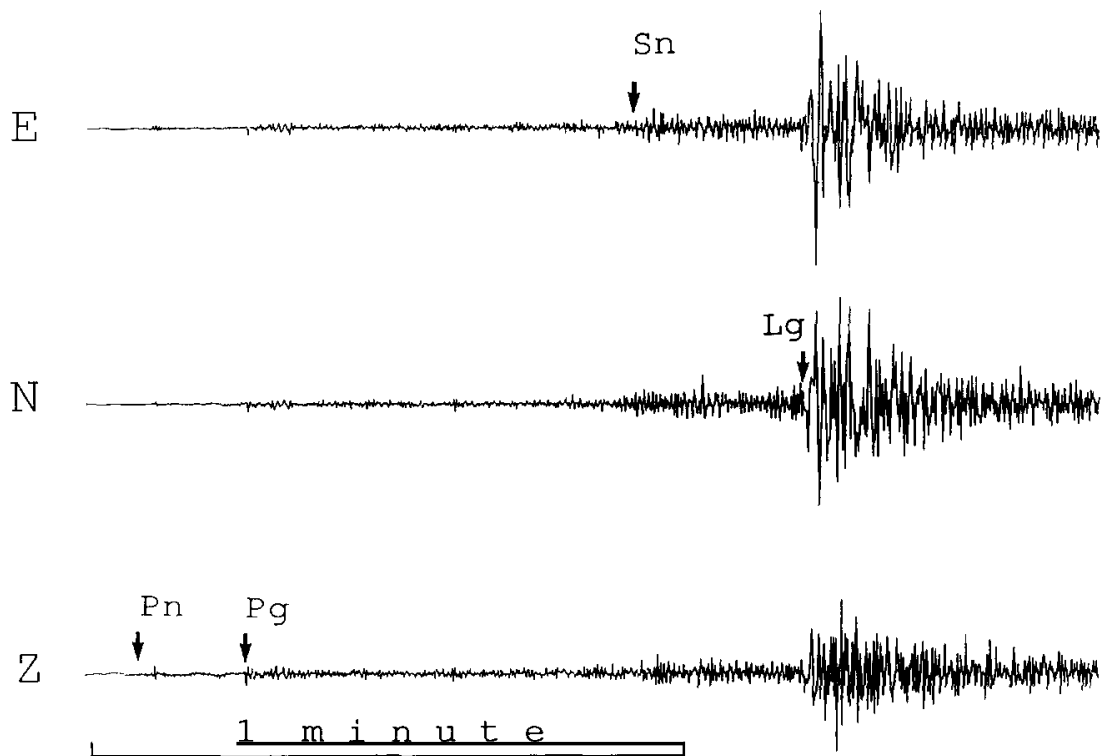

Fig. 3. Analog displays of digital three-component broad-band seismograms at Uppsala from the 1985 earthquake. The epicentral distance is $485 \mathrm{~km}$. Arrivals of major crustal phases are indicated. 


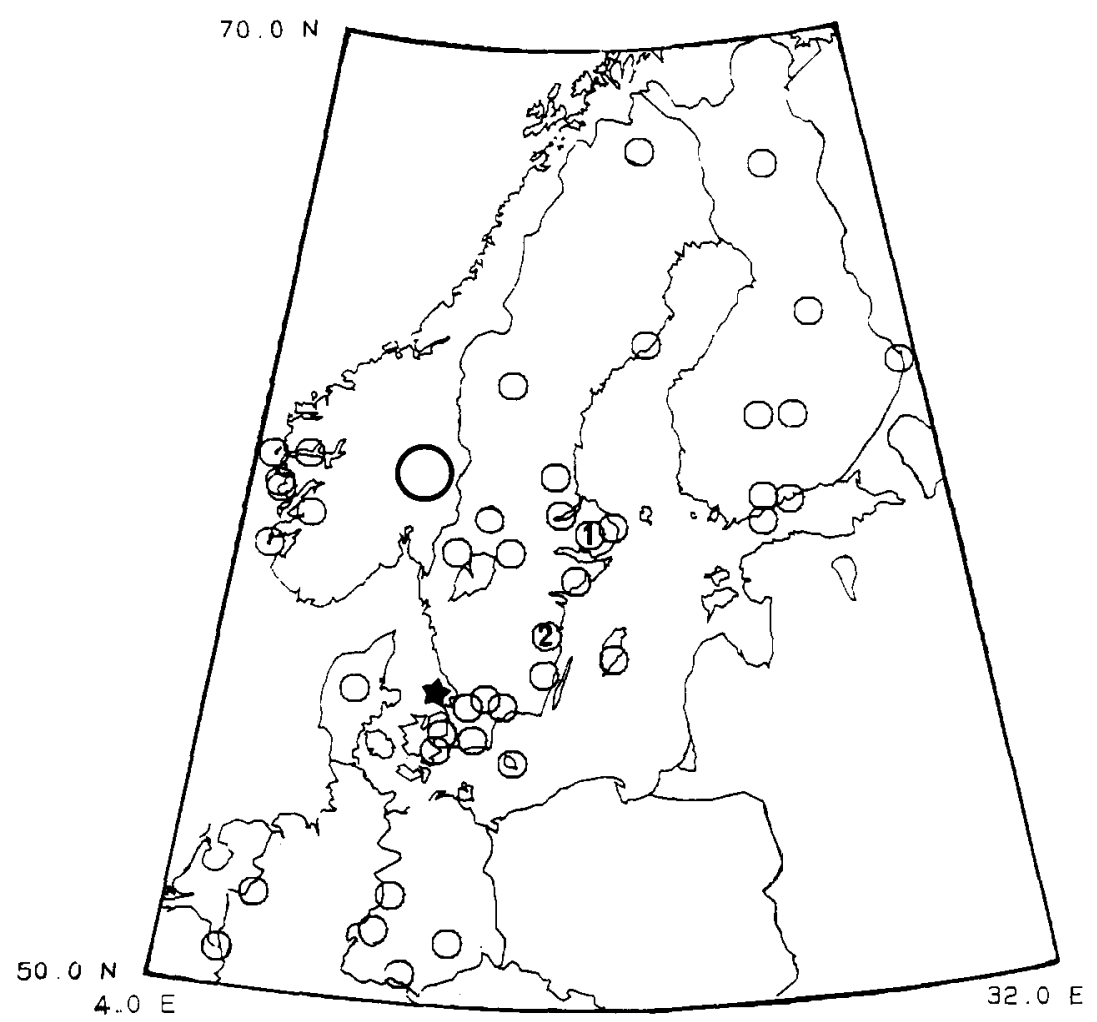

Fig. 4. Locations of stations used in the analysis. The large circle shows the location of NORSAR stations. The NRS station is operated as an independent part of NORSAR. The numbers denote (1) the Uppsala station (UPP) and (2) the Vimmerby station (VIM). The star indicates the site of the 1985, 1986 and 1990 earthquakes.

Denmark, the crustal thickness was assumed to be only $30 \mathrm{~km}$ (Bungum et al., 1980, EUGENO-S working group, 1988). Deduced hypocentral parameters are given in Table 2.

A minor aftershock field survey, including the deployment of three portable analog stations on the Swedish coast close to the epicentral area, was started two days after the 1985 earthquake. During several weeks of operation no certain aftershocks were recorded.

\section{Macroseismic investigation}

\subsection{The 1985 earthquake}

The 1985 earthquake was felt over a large part of southern and southwestern Sweden at intensities up to VI on the Modified Mercalli Scale
(MM). In eastern Denmark, the event was felt at intensities up to V. Reports indicate that in Torekov (Sweden) and neighbouring areas external walls cracked and windows broke. The outer limit (intensity II-III) of the area over which the earthquake was generally perceptible is well defined by the macroseismic surveys conducted by the Seismological Department, Uppsala University and the National Survey and Cadastre, Copenhagen. Approximately 500 written reports of intensity effects were received in response to questionnaires sent to postmasters in the area and to requests in local newspapers. In addition, a thorough survey of newspaper reports was carried out and local residents were interviewed. MM intensities were assigned to many sites and the resulting isoseismal map is shown in Fig. 5.

Figure 5 shows that the area of perceptibility is somewhat elongated in the north-south direction. 


\section{TABLE 2}

Source parameters

\begin{tabular}{|c|c|c|c|}
\hline Date & $15-06-1985$ & 01-04-1986 & $24-05-1990$ \\
\hline Origin time & 004021.3 & 095655.0 & 095156.8 \\
\hline Latitude $\left({ }^{\circ} \mathrm{N}\right)$ & 56.56 & 56.58 & 56.56 \\
\hline Longitude $\left({ }^{\circ} \mathbf{E}\right)$ & 12.25 & 12.30 & 12.06 \\
\hline Focal depth (km) & 11 & 10 & 17 \\
\hline \multicolumn{4}{|l|}{ Magnitude } \\
\hline$\left(\mathbf{M}_{\mathbf{L}}(\mathrm{UPP})\right)$ & & 3.3 \\
\hline $\begin{array}{l}\text { Maximum inten- } \\
\text { sity (MM) }\end{array}$ & & & - \\
\hline \multicolumn{4}{|l|}{ Nodal plane 1: } \\
\hline $\operatorname{dip}\left({ }^{\circ}\right)$ & $\begin{array}{l}312 \\
70\end{array}$ & $\begin{array}{l}331 \\
40\end{array}$ & $\begin{array}{l}328 \\
50\end{array}$ \\
\hline rake $\left({ }^{\circ}\right)$ & 165 & -154 & 176 \\
\hline \multicolumn{4}{|l|}{ Nodal plane 2: } \\
\hline strike $\left(^{\circ}\right)$ & 48 & 227 & 61 \\
\hline $\operatorname{dip}\left({ }^{\circ}\right)$ & 76 & 74 & 87 \\
\hline rake $\left({ }^{\circ}\right)$ & 21 & -53 & 40 \\
\hline $\mathrm{P}$-axis trend $\left({ }^{\circ}\right)$ & 179 & 176 & 188 \\
\hline plunge $\left({ }^{\circ}\right)$ & 4 & 48 & 24 \\
\hline T-axis trend $\left({ }^{\circ}\right)$ & 271 & 290 & 293 \\
\hline plunge $\left({ }^{\circ}\right)$ & 25 & 20 & 30 \\
\hline \multicolumn{3}{|l|}{ Seismic moment } & $6.0 \times 10^{12}$ \\
\hline \multicolumn{4}{|l|}{ Corner frequency } \\
\hline$(\mathrm{Hz})$ & 2.0 & 1.7 & 2.9 \\
\hline Source radius (m) & 670 & 790 & 460 \\
\hline \multicolumn{4}{|l|}{ Average disloca- } \\
\hline tion $(\mathrm{mm})$ & 7.7 & 2.2 & 0.3 \\
\hline Stress drop (MPa) & 0.52 & 0.12 & 0.03 \\
\hline $\mathrm{N}^{\mathrm{a}}$ & 12 & 12 & 1 \\
\hline
\end{tabular}

${ }^{a} \mathrm{~N}$ is number of stations used in the calculations of the dynamic source parameters. For the 1985, 1986 and 1990 earthquakes the maximum horizontal errors in the locations were $1.5,2.7$ and $3.2 \mathrm{~km}$, respectively and corresponding figures for the vertical location errors were $1.8,8.5$ and $3.8 \mathrm{~km}$.

The area of perceptibility was approximately $100000 \mathrm{~km}^{2}$, corresponding to a mean radius of about $180 \mathrm{~km}$. By using the Blake-Shebalin formula (see e.g. Karnik, 1969), we can estimate the focal depth from the macroseismic data. The formula reads

$I_{0}-I_{\mathrm{p}}=k \log _{10}\left[\left(r_{\mathrm{p}}^{2}+h^{2}\right)^{1 / 2} / h\right]$

where $I_{0}$ is the maximum intensity, $I_{\mathrm{p}}$ is the intensity at the level of perceptibility, $k$ is the coefficient of attenuation, $r_{p}$ is the radius of equivalent circular area of perceptibility and $h$ is the focal depth. Korhonen and Ahjos (1979) recommend the use of the values $k=4$ and $I_{\mathrm{p}}=2.5$ for the Baltic Shield. We apply these values even though the earthquakes took place at the brim of the shield. The epicentre being offshore, we further assume $I_{0}$ to be one degree higher than the maximum observed intensity, i.e. we put $I_{0}=$ VII. With a mean radius of perceptibility of $180 \mathrm{~km}$ (see above), introducing these entries into eqn. (1) gives a focal depth of $13 \mathrm{~km}$, in good agreement with the value $(11 \mathrm{~km})$ obtained from the arrivaltime location (Table 2).

The maximum intensity and radius of perceptibility can also be used to determine the macroseismic magnitude, $M_{\mathrm{M}}(\mathrm{UPP})$, from the formula of Wahlström and Ahjos (1984)

$M_{\mathrm{M}}(\mathrm{UPP})=0.38+1.14 \log _{10} r_{\mathrm{p}}+0.23 I_{0}$

Introducing the values $r_{\mathrm{p}}=180 \mathrm{~km}$ and $I_{0}=\mathrm{VII}$ into eqn. (2) we obtain a value for $M_{\mathrm{M}}$ (UPP) of 4.6 , i.e. the same as that for $M_{\mathrm{L}}$ (UPP).

\subsection{The 1986 earthquake}

The event in 1986 was felt in a limited region of southwestern Sweden with maximum intensity IV + . In eastern Denmark, the quake was felt with maximum intensity $\mathrm{V}$ at several rather scattered locations. The isoseismal map (Fig. 6) was compiled from approximately 300 questionnaire replies, direct interviews and newspaper reports. Many reports note swinging lamps and trembling buildings. Figure 6 shows that the macroseismic field is well constrained except in west and northwest directions. The area of perceptibility has a mean radius of about $100 \mathrm{~km}$. As in the previous case, the observed macroseismic field is somewhat elongated in the north-south direction. By analogy with the asymmetry of the maximum intensity of the 1985 earthquake we assume $I_{0}=\mathrm{VI}$ for the 1986 event. Equation (1) then again gives a focal depth of $13 \mathrm{~km}$, indicating the close proximity of the two hypocentres. The value of the macroseismic magnitude $M_{\mathrm{M}}$ (UPP) determined using eqn. (2) is 4.0 , which compares with a value for the instrumental magnitude $M_{\mathrm{L}}$ (UPP) of 4.2 . 


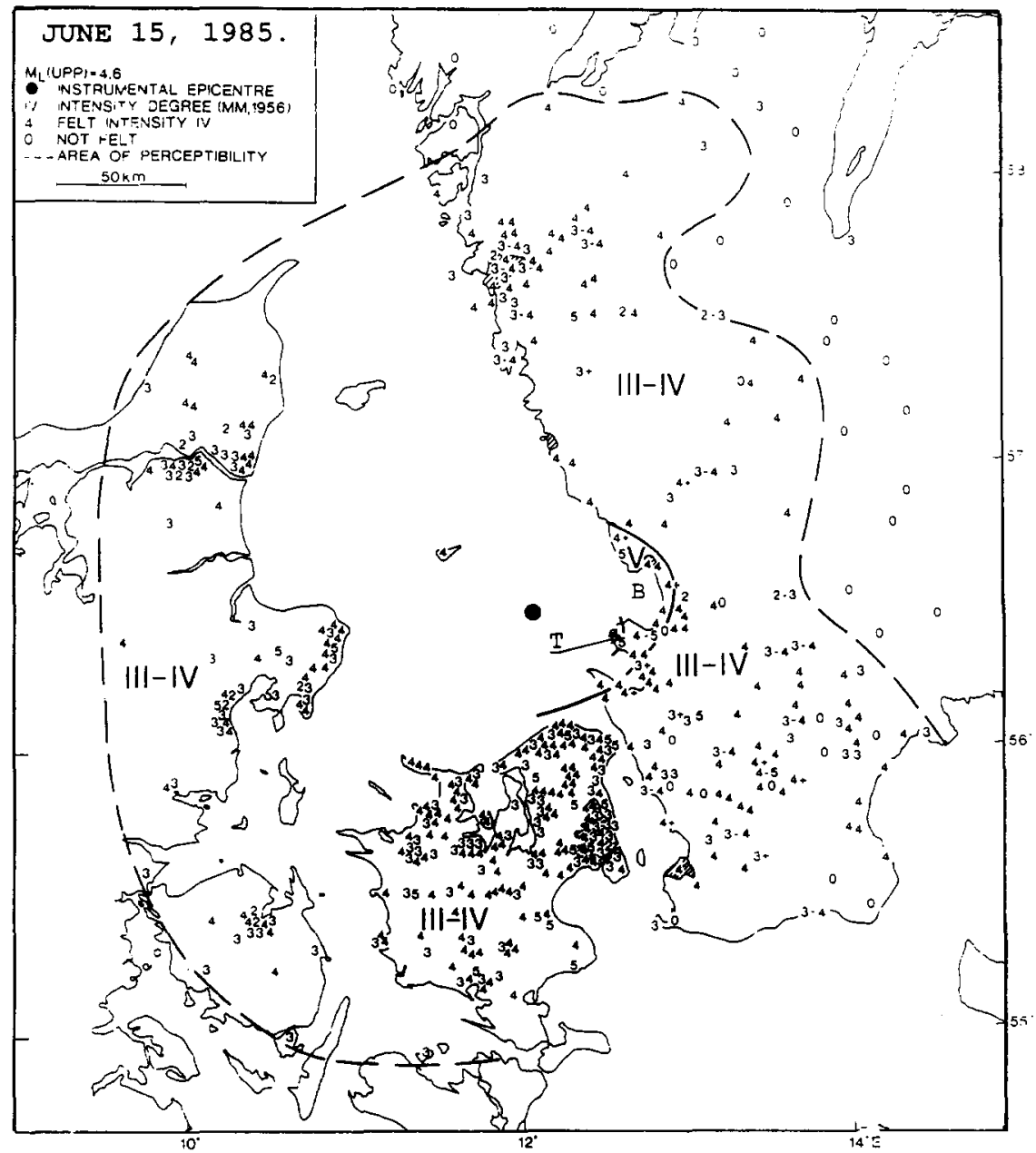

Fig. 5. Isoseismal map of the June 15, 1985 earthquake. T denotes Torekov, where minor damage was observed, and B denotes Bay of Laholm. Some coastal population centres are indicated by hatching.

\subsection{The 1990 earthquake}

The 1990 event was felt in only a limited coastal area of Sweden, north of the Bay of Laholm (for location, see Fig. 5). The usual postal survey resulted in about 90 reports of macroseismic effects. The maximum intensity IV was felt at several rather scattered localities. The limited macroseismic information indicates a shift of the macroseismic field northwards when compared with the fields of the 1985 and 1986 earthquakes. This difference is not consistent with the proximity of instrumental epicentral locations of all three earthquakes (Fig. 1; Table 2). Unfortunately, the scarcity of macroseismic data makes it impossible to elaborate further on this discrepancy or to estimate the focal depth and the macroseismic magnitude.

\subsection{The 1759 earthquake}

As a comparison, the 1759 earthquake that occurred in northern Kattegat (see above) had an estimated maximum intensity of VIII and a radius of perceptibility of approximately $500 \mathrm{~km}$ (Muir 


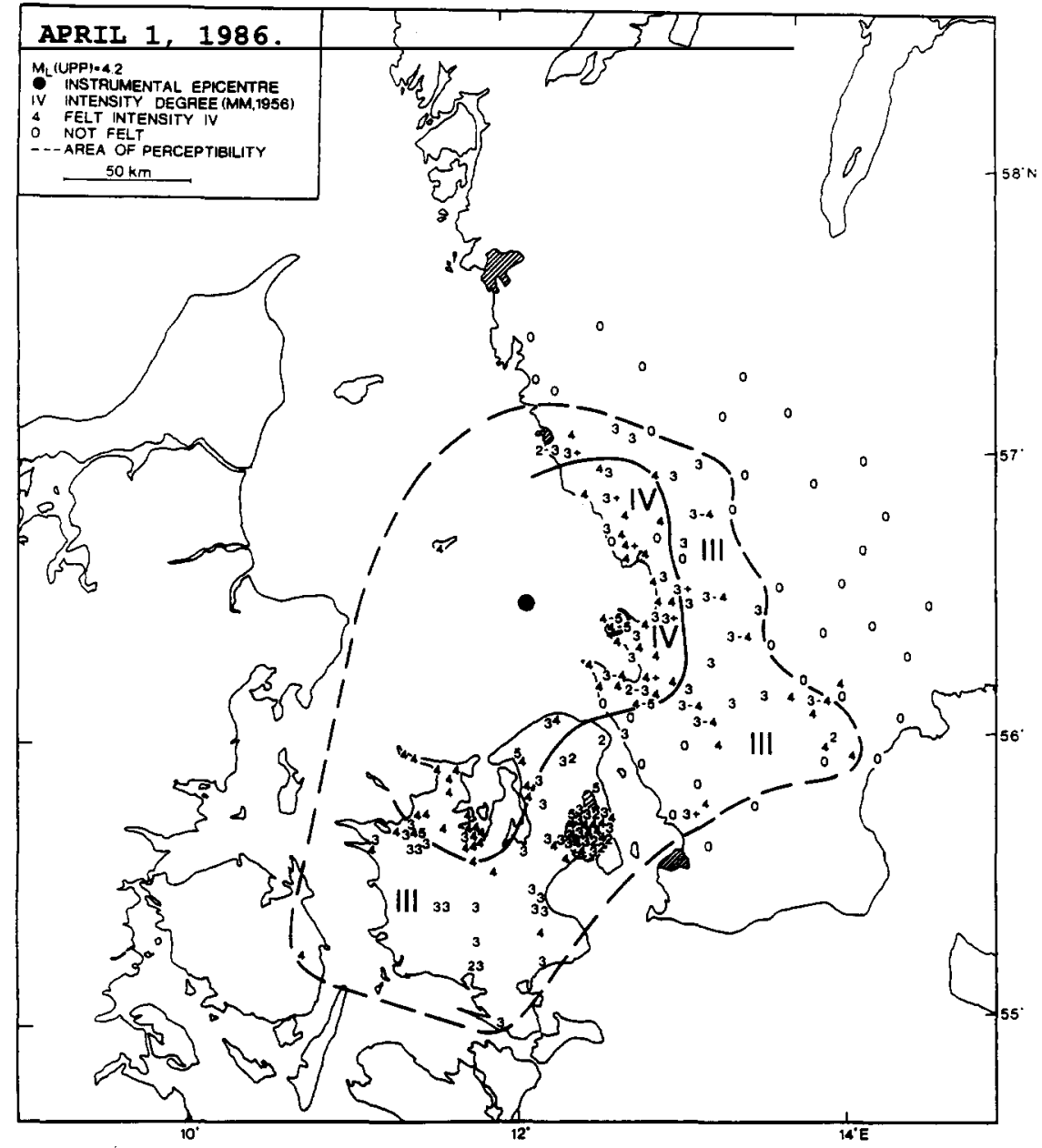

Fig. 6. 1soseismal map of the April 1, 1986 earthquake.

Wood, 1988). Again, the felt area was elongated in the north-south direction although for this large macroseismic area there is no clear limitation westward, in the North Sea.

\section{Focal mechanisms}

Focal mechanisms for the three earthquakes were derived from the polarities of first P-onsets. When searching for polarities, we made use only of data that we read ourselves. Seismograms from almost all available stations in Denmark, Finland, Norway and Sweden, together with a number of records from stations in Germany and Holland, were examined. In total, 33 polarities for the 1985 shock, 22 for the 1986 shock and 11 for the 1990 shock were finally used. Although data for the two largest events, in 1985 and 1986, were scarce to the south of the epicentres, there is a reasonably good azimuthal coverage by high-quality records. For the 1990 event, polarity readings were available only for azimuths ranging from NW clockwise to SE. For all events, measurements from stations at epicentral distances of $130-170 \mathrm{~km}$ were omitted because of difficulties with discrimination between $P_{g}$ and $P_{n}$ phases. Focal mechanisms were acquired by employing a modified version of the program FOCMEC (Snoke et al., 1984) which is based on an algorithm which searches the focal sphere for acceptable solutions. The present modification makes use of weighted data, with full weight for 
impulsive and half weight for emergent polarity readings. The program yields a family of focalplane solutions with minimized weight of polarity errors. For details on the modified FOCMEC program and the algorithm used, see Wahlström (1987).

The fault-plane solution for the 1985 earthquake shows predominantly strike-slip movement

JUNE 15, 1985 .

$\mathrm{N}$

N

$\mathrm{N}$

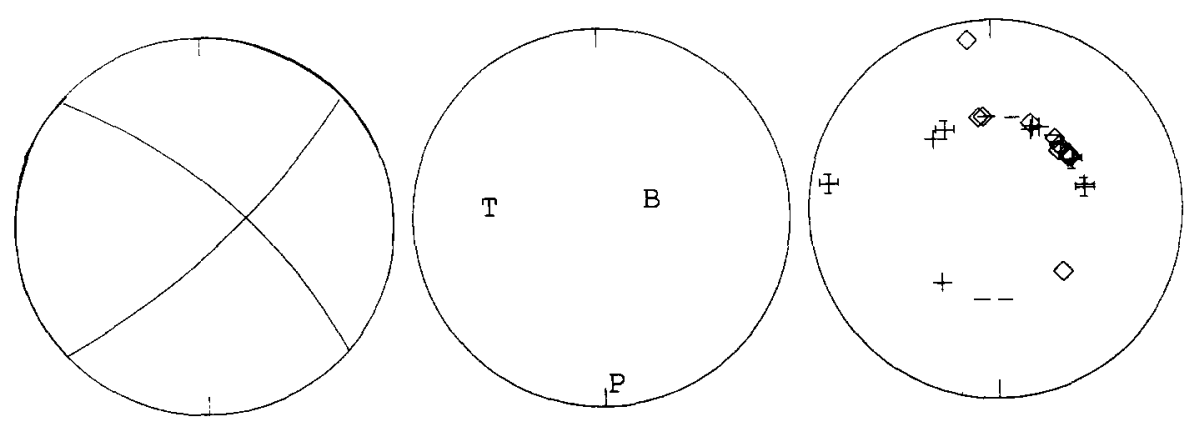

APRIL 1, 1986.

$\mathrm{N}$

N

$\mathrm{N}$

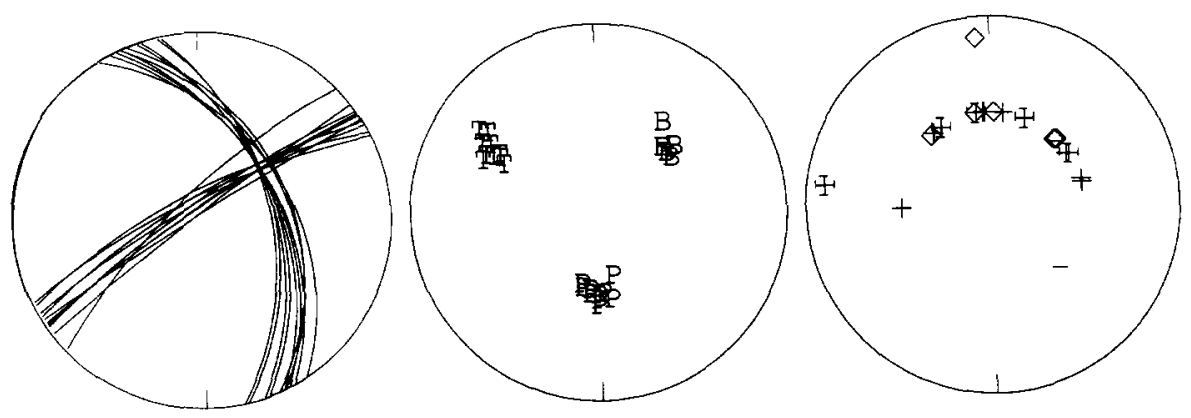

MAY 24, 1990.

N

N

N
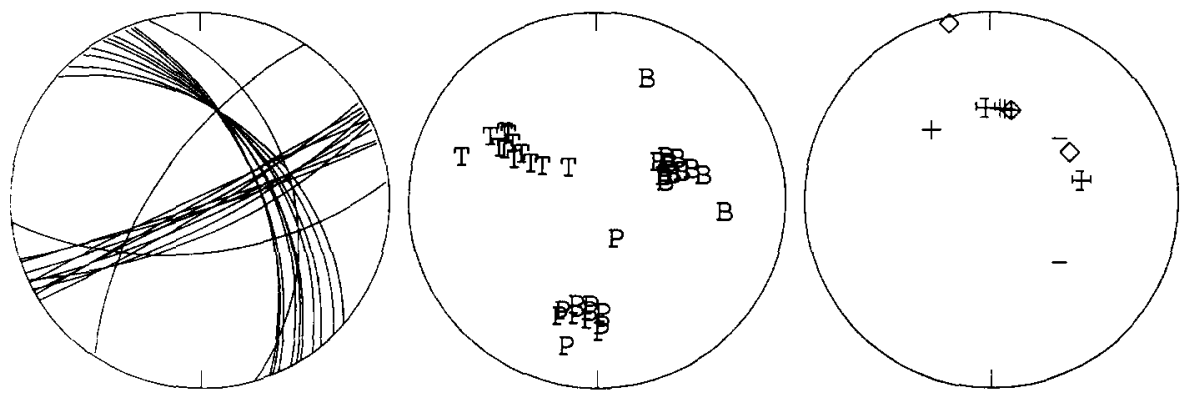

Fig. 7. Lower-hemisphere projections of fault-plane solutions from FOCMEC for the three investigated earthquakes showing distributions of nodal planes (left), compressional (P) and tensional (T) axes, and null vectors (B) (middle), and polarity data (right). + :full-weighted compressive P-polarity; + :half-weighted compressive P-polarity; $\diamond:$ full-weighted dilatational P-polarity; -:halfweighted dilatational $P$-polarity. 
on steeply dipping nodal planes striking NW or SW (Fig. 7; Table 2). For the 1986 earthquake, the focal-mechanism solution is similar to that for the 1985 event. The NW-oriented nodal plane indicates strike-slip faulting with a minor normalfaulting component (Fig. 7; Table 2). The focal mechanism for the 1990 event resembles those for the other two earthquakes. Of 12 solutions (Fig. 7; Table 2), 11 give a similar mechanism to that in the two previous cases, with the NW plane showing strike-slip with a minor thrust component. The remaining solution gives a normal-faulting style.

As can be seen in Fig. 7 and Table 2, the approximately north-south orientation of the deduced P-axes is consistent for all three events studied. However, only the 1985 shock has an almost horizontal P-axis. Also the east-west orientation of the T-axes is similar for all three shocks. Even though all mechanisms show predominantly strike-slip faulting, there are differences between individual events. For example, the polarity at VIM (Fig. 4) for the 1985 and 1986 events is opposite to that for the 1990 event.

The main tectonic features in Kattegat, like the Tornquist zone, the Anholt fault and the Skälderviken depression, strike NW (Fig. 1). This is observed directly from lineaments and faults in the area. The NW direction is further supported by interpretations of seismic and geological findings made by Lykke-Andersen (1987). Thus, it seems reasonable to assume that the earthquakes studied occurred along the NW-striking nodal planes obtained in the focal-mechanism solutions (Fig. 7).

\section{Dynamic source parameters}

Dynamic source parameters, such as seismic moment, source radius, average dislocation and stress drop, were estimated from Lg-wave displacement spectra deduced from vertical-component analog and digital seismograms. The number of stations used in the analysis of each of the three events can be found in Table 2 . The window length of the Lg-wave used for spectral estimates varied from $7 \mathrm{~s}$ to $35 \mathrm{~s}$ depending on the length of the Lg-coda. The sampling rate of the digital records was $83 \mathrm{~Hz}$ for the Uppsala broad-band station, $60 \mathrm{~Hz}$ for the SKI-stations (operated by the National Defense Research Institute, Sweden) and $40 \mathrm{~Hz}$ for the NORESS array (NRS; operated by NORSAR Norway). Seismograms from analog stations were photographically enlarged five times and electronically digitized on a Tektronix 4958 digitizing table. The digitized data were detrended and interpolated to obtain equal sampling intervals of $0.025 \mathrm{~s}$ by making use of the piecewise continuous cubic polynomial (Wiggins, 1976). Fourier transformation of the digital data yields trace amplitude spectra and correction for the instrument response yields ground-motion spectra. Examples of ground amplitude spectra are shown in Fig. 8.

The seismic moment, $M_{0}$, is computed from the low-frequency spectral level, $\Omega_{0}$, according to (Street et al., 1975, Herrmann and Kijko, 1983)

$M_{0}=\left\{\begin{array}{lll}4 \pi \rho \beta^{3} R_{0}\left(R / R_{0}\right) \Omega_{0} & \text { for } & R<R_{0} \\ 4 \pi \rho \beta^{3} R_{0}\left(R / R_{0}\right)^{1 / 2} \Omega_{0} & \text { for } & R \geqslant R_{0}\end{array}\right.$

where $\rho$ is the density $\left(2.7 \mathrm{~g} \mathrm{~cm}^{-3}\right), \beta$ is the shear wave velocity $\left(3.6 \mathrm{~km} \mathrm{~s}^{-1}\right), R_{0}$ is the reference distance $(100 \mathrm{~km})$ and $R$ is the epicentral distance. The assigned value of $R_{0}$ reflects the distance over which $\mathrm{Lg}$-waves are believed to change from body-wave type (spherical spreading) at shorter distances to mainly surface-wave type (cylindrical spreading) at longer distances (Street et al., 1975). To determine $\Omega_{0}$ and the corner frequency $f_{\mathrm{R}}$ the calculated spectra, plotted as $\log -\log$ diagrams, were approximated by two straight lines. A horizontal line was drawn by eye through the long-period portion of each spectrum. Another line was drawn through the high frequency portion. $f_{\mathrm{R}}$ was taken to be the frequency at which the two lines intersect. When $\Omega_{0}$ is determined from vertical-component $\mathrm{Lg}$ records Herrmann and Kijko (1983) recommend the use of the logarithmic mean, in the low frequency range, multiplied by a factor of two. This procedure has been followed in the present analysis. The anelastic attenuation of the propagation paths 


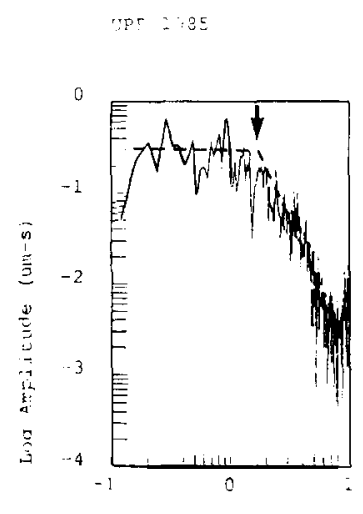

LOg Freguicicy (Hz)

NhS 1986

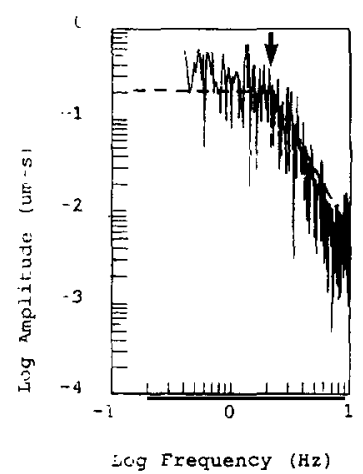

NRE 1335

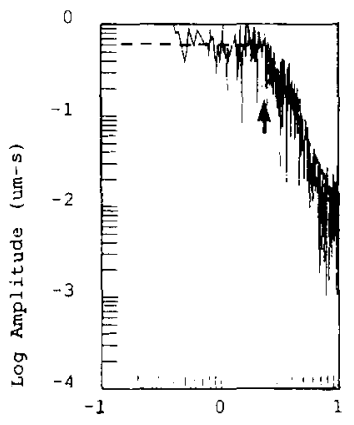

Log Frequency $\{\mathrm{Hz}\}$

NRS 1990

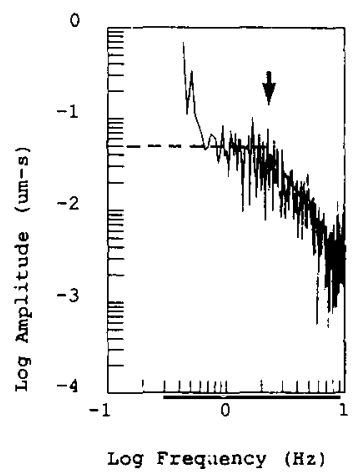

Fig. 8. Ground amplitude displacement spectra of the 1985 earthquake recorded by vertical-component broad-band station at Uppsala (upper left; cf. Fig. 3). Spectra deduced from records made at NORESS (NRS) are displayed for the 1985,1986 and 1990 events at the upper right, lower left and lower right, respectively. Dashed lines show the linear approximations of the short- and long-period portions of the spectra. The intersection of the two lines determines the corner-frequency (arrow). No efforts have been made to keep the high-frequency slope equal to -2 .

is not very well known and is consequently not taken into account in the estimation of $\Omega_{0}$. However, this simplification has only an insignificant influence at moderate distances (about $500 \mathrm{~km}$ ), frequencies less than $1 \mathrm{~Hz}$ and a quality factor of about 1000 (see e.g. Kim et al., 1989). There is no significant difference between the spectral parameters obtained from analog or digital stations.

The source-spectrum corner frequency, $f_{0}$, is extrapolated from the observed corner frequency, $f_{\mathrm{R}}$, via an empirical relationship derived for the Baltic Shield (Kim et al., 1989). It takes into account the attenuation of the higher frequencies and reads

$\log \left(f_{0}\right)=\log \left(f_{R}\right)-R k$

where $k\left(\mathrm{~km}^{-1}\right)$ is the attenuation factor, which decreases with increasing event size (see Kim et al., 1989).

The source radius, $r$, average dislocation, $D_{0}$, and stress drop, $\Delta \sigma$, were computed from the formulae (Aki, 1966, Brune, 1970,1971)

$r=2.34 \beta /\left(2 \pi f_{0}\right)$

$D_{0}=M_{0} /\left(\mu \pi r^{2}\right)$

$\Delta \sigma=M_{0}(7 / 16)\left(1 / r^{3}\right)$

where $\mu$ is the shear modulus $\left(3.3 \times 10^{10} \mathrm{~N} \mathrm{~m}^{-1}\right)$.

The source parameters obtained are listed in Table 2. Note the low stress drop deduced for all three events studied. For the 1985 and 1986 events the values parallel those of Kulhánek et al. (1981, 1983) and Kim et al. (1989) for other earthquakes in Fennoscandia. The 1990 event provided only one useful spectrum and the deviation of the value of the stress drop from the spectral scaling relations for Fennoscandia (Kim et al., 1989) is thus uncertain.

\section{Discussion}

A glance at Fig. 7 suggests that the focal mechanisms of the three earthquakes studied here are all predominantly of a strike-slip style on the preferred NW-oriented plane, although the 1985 and 1990 shocks have a small thrust component, whereas the 1986 shock has a small normal component. The similarity between the first two events is emphasized when comparing the isoseismal maps (Figs. 5 and 6). Taking into consideration also the proximity of the three earthquakes, it is reasonable to assume that they were generated by a similar stress field and took place on the same fault system. 
Various causes have been proposed for the present tectonism in Fennoscandia. Major mechanisms generating earthquakes in Fennoscandia may be the reactivation of older faults due to postglacial rebound (Båth, 1954; Lagerbäck, 1979; Mörner, 1979; Wahlström, 1989; Bungum et al., 1990), and stress propagation from the North Atlantic Ridge, the nearest active plate margin, which would imply a NW-oriented compressive stress field (Slunga, 1989; Wahlström, 1989; Bungum et al., 1991; Skordas et al., 1991). Sedimentation and erosion effects may also have some influence (Turcotte and Oxburgh, 1976; Bungum et al., 1990).

The orientation of the $P$-axes of all three earthquakes in the north-south direction, and the fairly steep plunge of the respective axis for the 1986 and 1990 earthquakes, are in contrast to the plethora of microearthquake mechanisms obtained for southern Sweden (Slunga, 1989). The latter generally follow a pattern of horizontal NW-oriented compression, which is in accordance with theories of global tectonics of stress propagation from ridge push at the North Atlantic Ridge. This stress is released inside the plates in zones of weakness created during earlier tectonic episodes. The ridge push postulates a NW-directed principal compressive stress which deviates by $45^{\circ}$ from our north-south trending P-axes. It could be argued that this $45^{\circ}$ deviation is due to local structures. Even though a maximum deviation of $45^{\circ}$ of the $\mathrm{P}$-axis trend from the direction of the principal compressive stress is possible (McKenzie, 1969), it seems to us likely that local tectonics is the major factor for the strong energy release. The reasons are several:

- The associated Skälderviken depression is the largest neotectonic feature in Kattegat and is the major site of seismic energy release in the area.

- The faulting observed recently on the northeastern flank of the Skälderviken depression (Lind and Lykke-Andersen, 1990) coincides with the locations of the 1985, 1986 and 1990 earthquakes.

- The depression is a feature created by a tensional regime (Lykke-Andersen, 1987) and not by a compressive plate-tectonic regime, which of course does not preclude interaction with a stress field associated with global tectonics.

\section{Acknowledgement}

We appreciate the assistance of $\mathrm{H}$. Bungum who critically reviewed the manuscript and contributed valuable comments and suggestions. We thank L. Monrad for assisting in the collection of macroseismic information for Denmark, G. Lind for valuable discussion and T. van Eck for operating the field stations after the 1985 earthquake. We are also very grateful for the seismograms provided by different agencies. $\mathrm{R}$. Wahlström was supported by research contract G-GU 4012-303 from the Swedish Natural Science Research Council.

\section{References}

Aki, K., 1966. Scaling law of seismic spectrum. J. Geophys. Res., 72: 1217-1231.

Ambraseys, N. N., 1985. The seismicity of western Scandinavia. J. Earthquake Eng. Struct. Dyn., 13: 361-399.

Båth, M., 1954. Seismicity of Fennoscandia and related problems. Gerl. Beitr. Geophys., 63: 173-206.

Båth, M., 1956. An earthquake catalogue for Fennoscandia for the years 1891-1950. Sveriges Geologiska Undersökning, Ser. C, 545: 52 pp.

Băth, M., 1979. Earthquakes in Sweden 1951-1976. Sveriges Geologiska Undersökning, Ser. C, 750: 79 pp.

Bergström, J., 1984. Lateral movements in the Tornquist Zone. Geologiska Föreningens i Stockholm Förhandlingar (GFF), 106: $379-380$.

Brune, J. N., 1970. Tectonic stress and the spectra of seismic shear waves from earthquakes. J. Geophys. Res., 75: 49975009.

Brune, J. N., 1971. Correction to tectonic stress and the spectra of seismic shear waves from earthquakes. J. Geophys. Res., 76: 5002 .

Bungum, H., Pirhonen, S. E. and Husebye, E. S., 1980. Crustal thicknesses in Fennoscandia. Geophys. J. R. Astron. Soc., 63: 759-774.

Bungum, H., Alsaker, A., Kvamme, L. B. and Hansen, R. A., 1991. Seismicity and seismotectonics of Norway and nearby continental shelf areas. J. Geophys. Res., in press.

EUGENO-S working group, 1988. Crustal structure and tectonic evolution of the transition between the Baltic Shield and the North German Caledonides (the EUGENO-S project). Tectonophysics, 150: 253-348.

FENCAT, 1990. Catalogue of Fennoscandian earthquakes. Institute of Seismology, University of Helsinki, Finland.

Herrmann, R. B. and Kijko, A., 1983. Modeling some empirical vertical component $\mathrm{Lg}$ relations. Bull. Seismol. Soc. Am., 73: 157-171. 
Husebye, E. S., Bungum, H., Fyen, J. and Gjöystdal, H., 1978 Earthquake activity in Fennoscandia between 1497 and 1975 and intraplate tectonics. Norsk Geologisk Tidsskrift, 58: $51-68$.

Karnik, V., 1969. Seismicity of the European Area. Part I, Reidel, Dordrecht, 364 pp.

Kim, W.-Y., Wahlström, R. and Uski, M., 1989. Regional spectral scaling relations of source parameters for earthquakes in the Baltic Shield. Tectonophysics, 166: 151-161.

Klein, F. W., 1978. Hypocenter location program: HYPOINVERSE, part 1: Users guide. Open file report 78-694, U. S. Geological Survey, Menlo Park, California: 113 pp.

Korhonen, H. and Ahjos, T., 1979. A contribution to the macroseismic investigations of earthquakes felt in Finland. Inst. Seismol., Univ. Helsinki, Report S-4: 21 pp.

Kulhánek, O., John, N., Meyer, K., van Eck, T. and Wahlström, R., 1981. Source parameters and seismotectonic implications of the recent Bergshamra, Sweden, earthquake. Earth Evolution Sci., 1: 66-70.

Kulhánek, O., van Eck, T., John, N., Meyer, K. and Wahlström, R., 1983. Spectra of the earthquake sequence FebruaryMarch, 1981, in south-central Sweden. Tectonophysics, 93 : 337-350.

Lagerbäck, R., 1979. Neotectonic structures in northern Sweden. Geologiska Föreningens i Stockholm Förhandlingar (GFF), 100: 263-269.

Lind, G. and Lykke-Andersen, H., 1990. Quaternary tectonics in Kattegat. Annales Geophysicae, special issue, EGS XV General Assembly, Copenhagen 23-27 April, 1990, pp. 33-34 (abstract).

Lykke-Andersen, H. L., 1987. Thickness of Quaternary deposits and their relation to the pre-Quaternary in the Fennoscandian border zone in Kattegat and Vendsyssel. BOREAS, 16: 369-371.

McKenzie, D. P., 1969. The relation between fault plane solutions for earthquakes and the directions of the principal stresses. Bull. Seismol. Soc. Am., 59: 591-601.

Mörner, N.-A., 1969. The late Quaternary history of the Kattegat and the Swedish west coast: deglaciation, shorelevel displacement, chronology, isostasy and eustacy. Sveriges Geologiska Undersökning, Ser. C, 640: 487 pp.

Mörner, N.-A., 1979. Earth movements in Sweden, 20.000 BP to 20.000 AP. Geologiska Föreningens i Stockholm Förhandlingar (GFF), 100: 279-286.

Muir Wood, R., 1988. The Scandinavian earthquakes of 22 December 1759 and 31 August 1819. Disasters, J. Disaster Stud. Manage., 12: 223-236.
Pegrum, R. M., 1984. The extension of the Tornquist Zone in the Norwegian North Sea. Norsk Geologisk Tidsskrift, 64: 39-68.

Skordas, E., Meyer, K., Olsson, R. and Kulhánek, O., 1991. Causality between interplate (North Atlantic) and intraplate earthquakes. Tectonophysics, 185: 295-307.

Slunga, R. S., 1989. Focal mechanisms and crustal stresses in the Baltic Shield. In: S. Gregersen and P. Basham (Editors), Earthquakes at the North-Atlantic passive margins: Neotectonics and postglacial rebound. Proceedings of NATO Advanced Research Workshop, Vordenborg, Denmark, May 9-13, 1988, Kluwer, Dordrecht, Ser. C-266: 799 pp. , 261-276.

Snoke, J. A., Munsey, J. W, Teague, A. G. and Bollinger, G. A., 1984. A program for focal mechanism determination by combined use of polarity and SV-P amplitude ratio data. Earthquake Notes, 55-3: 15.

Street, R. L., Herrmann, R. B. and Nuttli, O. W., 1975. Spectral characteristics of the $\mathrm{Lg}$ wave generated by central United States earthquakes. Geophys. J. R. Astron. Soc., 41: 51-63.

Turcotte, D. L. and Oxburgh, E. R., 1976. Stress accumulation in the lithosphere. Tectonophysics, 35: 183-199.

Wahlström, R., 1987. Focal mechanisms of earthquakes in southern Quebec, southeastern Ontario, and northeastern New York with implications for regional seismotectonics and stress field characteristics. Bull. Seismol. Soc. Am., 77: 891-924.

Wahlström, R., 1989. Seismodynamics and postglacial faulting in the Baltic Shield. In: S. Gregersen and P. Basham (Editors), Earthquakes at North-Atlantic passive margins: Neotectonics and postglacial rebound. Proceedings of NATO Advanced Research Workshop, Vordenborg, Denmark, May 9-13, 1988, Kluwer, Dordrecht, Ser. C-266: 799 pp. , 467-482. Publ. 159 of the International Lithosphere Program.

Wahlström, R., 1990. A catalogue of earthquakes in Sweden in 1375-1890. Geologiska Föreningens i Stockholm Förhandlingar (GFF), 112: 215-225.

Wahlström, R. and Ahjos, T., 1984. Magnitude determination of earthquakes in the Baltic Shield. Annales Geophysicae, 2: 553-558.

Wiggins, R. A., 1976. Interpolation of digitized curves. Bull. Seismol. Soc. Am., 66: 2077-2081. 